\title{
Childhood trauma and the prevalence of alcohol dependence in adulthood
}

Trauma w dzieciństwie a występowanie uzależnienia od alkoholu w dorosłym życiu

\author{
Karolina Kosecka ${ }^{1}$ BEF, Ewa Stelmach ${ }^{2}$ AD, https://orcid.org/0000-0001-7866-6556 \\ ${ }^{1}$ Gastrology Department, Voivodeship Specialist Hospital of Lublin \\ ${ }^{2}$ II Department of Psychiatry and Psychiatric Rehabilitation, Medical University of Lublin
}

\begin{abstract}
Introduction: The experience of trauma and stress in childhood and early adulthood can lead not only to immediate physical and psychological symptoms but also to long-term effects observed in later life.

Aim and method: The objective of the following study was to search for the correlation between the occurrence of childhood trauma and its long-term outcome, that is alcohol dependence, and to review studies concerning the presence of certain personality traits in patients with such trauma experience and prognostic factors for treatment. The literature in the Google Scholar database was reviewed using the following keywords: childhood abuse, childhood trauma, alcohol addiction and alcohol use disorder. The time descriptors 2015-2021 were also used.

Results: On the basis of the conducted studies, it has been found that the experience of extremely stressful situations at a young age is declared by a greater part of the examined patients with alcohol dependence syndrome. It was also noticed that the most significant and most frequently reported negative childhood experiences in patients with alcohol dependence syndrome are physical violence, parental separation or divorce, and mental illness of a family member. It was found that impulsivity, disorder, pessimism, fatigue and asthenia are some of the characteristics of this group of patients.

Conclusions: It can be concluded that there is a significant correlation between the occurrence of traumatic events in childhood and the tendency to develop alcohol addiction in adulthood.
\end{abstract}

Keywords: childhood abuse, childhood trauma, alcohol addiction, alcohol use disorder

\section{Streszczenie}

Wstęp: Występowanie traumy i stresu w dzieciństwie i w okresie wczesnej dorosłości może nieść za sobą skutki nie tylko bezpośrednie związane z obszarem fizycznym oraz psychiczne, ale także długofalowe obserwowane w późniejszym wieku.

Cel i metoda: Celem pracy było poszukiwanie zależności pomiędzy występowaniem traumy u dzieci a jej dalekofalowym skutkiem jakim jest uzależnienie od alkoholu oraz przegląd badań dotyczący występowania pewnych charakterystycznych cech osobowości u pacjentów z doświadczeniem traumy dziecięcej i czynników prognostycznych w terapii. Dokonano przeglądu literatury za pomocą Google Scholar, uży wając słów kluczy trauma dziecięca, przemoc w dzieciństwie, zespół uzależnienia od alkoholu oraz dyskryptorów czasowych 2015-2021.

Wyniki: Na podstawie przeprowadzonych badań stwierdzono, że doświadczenie ekstremalnych sytuacji stresowych w młodym wieku deklaruje większa część badanych pacjentów z zespołem uzależnienia od alkoholu oraz zauważono, że najistotniejszymi i najczęściej raportowanymi negatywnymi doświadczeniami z dzieciństwa u pacjentów z zespołem uzależnienia od alkoholu są przemoc fizyczna, separacja lub rozwód rodziców oraz choroba psychiczna członka rodziny. Stwierdzono również, że jednymi z cech charakteryzujących tę grupę chorych są impulsywność, dezorganizacja, pesymizm, męczliwość i astenia.

Wnioski: Na podstawie aktualnej wiedzy medycznej można stwierdzić, że istnieje znacząca korelacja pomiędzy występowaniem traumatycznych wydarzeń w wieku dziecięcym a skłonnością do uzależnienia od alkoholu w wieku dorosłym.

Słowa kluczowe: trauma dziecięca, przemoc w dzieciństwie, zespół uzależnienia od alkoholu 


\section{Introduction}

In the contemporary world, there is a growing awareness of the fact that many stressful life events can affect the development of addictions, including alcohol dependence. The experience of trauma and stress in childhood and early adulthood can lead not only to immediate physical (e.g. wounds, injuries) and psychological (e.g. anxiety, child's self-isolation) symptoms but also to long-term effects observed in later life [1-4].

According to the World Health Organization's (WHO) definition, violence against children refers to experiencing abuse or neglect by a person under 18 years of age. Under this definition, violence against children is understood as all types of physical and emotional ill-treatment, sexual abuse and exploitation, neglect, sexual harassment, exploitation for financial gain, which consequently have a negative impact on a child's development, life and health. Furthermore, the WHO specifies four types of violence against children, i.e. physical abuse, sexual abuse, emotional abuse, and emotional neglect [5].

Lee et al. indicate that in early developmental stages, when neuroplasticity is high, exposition to early childhood traumas may cause changes in physiological stress system and reward system and lead to post-traumatic stress disorders and tendency to alcohol abuse in adulthood [6].

On the basis of the conducted research, it can be concluded that early childhood stress causes changes in the physiological stress system and brain's reward system, which is also responsible for the pathophysiology of addiction. Stressors occurring in early life lead to changes in the functioning of hypothalamic-pituitary-adrenal axis [7-8]. Zhang et al. [9] and Lee et al. [6] also emphasized the role of the hypothalamic-pituitary-adrenal axis dysregulation in patients addicted to alcohol with childhood trauma history. Prolonged and intense cortisol secretion, which is a response to chronic stress, results in decreased expression of genes for cortisol receptor followed by increased expression of corticoliberin in the hypothalamus [7-8]. Corticoliberin modulates the levels of catecholamines in the central nervous system, including cortico-striatal-limbic circuits, which are part of the reward system. The aforementioned changes in the functioning of the nervous system contribute to alcohol abuse [10].

Structural and functional neuroimaging showed that stressors presence in early stages of life, occurrence of childhood trauma or chronic stress may lead to lower gray matter volume in medial prefrontal cortex, amygdala, hippocampus and also insula regions. These stressors listed above may decrease responses in prefrontal regions responsible for working memory, reward system, resilience coping and, connected with the tendency do risk alcohol use, binge eating and aggressive behaviours [11].
On the basis of the conducted research, it has been concluded that the more severe the trauma, the more serious its consequences in adulthood [1-4]. The definition of childhood stress is understood as any traumatic event experienced before the age of 18. The most common traumas include sexual, emotional and physical abuse, stressful events such as death, loss of one or both parents, domestic violence, extremely poor living conditions, and poverty $[2,3,5]$.

\section{Aim of the study}

The objective of the following study was to search for the correlation between the occurrence of childhood trauma and its long-term outcome, that is alcohol dependence. The aim was also to review latest studies concerning the presence of certain personality traits in patients with the experience of such trauma and prognostic factors for treatment.

\section{Methods}

The literature in the Google Scholar database was reviewed using the following keywords: childhood abuse, childhood trauma, alcohol addiction and alcohol use disorder. The time descriptors 2015-2021 were also used.

\section{Results}

urrent medical knowledge allows to put forward a thesis that there is a correlation between the occurrence of trauma in childhood and alcohol dependence in adulthood. On the basis of the conducted studies, it has been found that the experience of extremely stressful situations at a young age is declared by a greater part of the examined patients with alcohol dependence syndrome $[2,3]$. In comparison, individuals without a history of alcohol dependence represent a ten times smaller group of patients who experienced abuse in childhood [1]. On the basis of current medical knowledge, a correlation between the occurrence of extremely stressful situations among pregnant women and the subsequent alcohol dependence of their children has not been proven with certainty (most of such studies have been conducted on animals according to ethics) [12]. However, based on a study from 2020, no significant correlations between traumatic events during pregnancy and early childhood, and the development of addiction in adulthood has been found. It has been concluded, nevertheless, that low-alcohol beverage consumption and frequent drinking by mother during pregnancy may predispose to the occurrence of alcohol dependence syndrome in men [13].

On the basis of the conducted research, it was also noticed that the most significant and most frequently reported negative childhood experiences in patients with alcohol dependence syndrome are physical violence, 
parental separation or divorce, and mental illness of a family member. There are also gender differences in the respective types of childhood events. Men much more often reported physical violence, sexual abuse, emotional neglect, and family malfunction. Women additionally noted emotional abuse and physical neglect. There is also a group of patients who experienced all the defined types of childhood trauma - it was observed that this group of patients additionally developed clinically significant mental disorders [1].

Vaughan et al. conducted a very interesting study concerning tendency to alcohol and other psychoactive substances abuse based on mice model. Mice were divided into groups concerning age and sex, they were exposed to stressors and different environmental factors. Authors observed important correlation between childhood trauma and higher risk of alcohol abuse in adulthood, especially in women, which can be modified by enriching environmental factors [14].

It is also worth emphasizing the relationship between the occurrence of childhood trauma and the personality traits of the described adult patients. Based on a 2015 study, it was found that impulsivity, disorder, pessimism, fatigue and asthenia are some of the characteristics of this group of patients. The researchers concluded that these patients, to a greater extent, have a lower level of frustration tolerance, are more excitable, impulsive, seek stimulation more actively, are less systematic in their actions, and engage in activities unrestricted by rules and principles. They are also affected by a low level of selfacceptance, lower understanding for the needs and feelings of others. It has been observed that these patients show a higher level of aggression, which may also predispose them to a higher risk of suicide $[15,16]$. Comparing this group of respondents to the general population, it can be concluded that they are also characterized by a higher level of generalized anxiety, which is a negative prognostic factor in therapy [17-19].

The coexistence of childhood trauma and alcohol addiction poses many therapeutic challenges. A low age of alcohol initiation was observed in this group of patients. Moreover, they developed alcohol dependence syndrome much earlier and the disease itself was clearly more severe [20,21]. The abovementioned personality traits in patients with alcohol dependence syndrome may predispose to therapeutic failures and early relapse after treatment for alcohol addiction [1,17,22,23]. In the 2019 study, researchers concluded that during the 12-month follow-up period, the group of women with a history of childhood trauma returned to addiction much more often than women without comorbid stress [24]. The treatment of such a group of patients should be focused on a comprehensive approach. The addiction itself and the childhood trauma itself must not be treated as separate disease cases. According to the latest research, the most effective method is to conduct the therapy simultaneously, addressing the problem of childhood trauma and addiction. The patient should be directed in such a way as to notice the cause-and-effect process [4].

\section{Conclusions}

Based on current medical knowledge, it can be concluded that there is a significant correlation between the occurrence of traumatic events in childhood and the tendency to develop alcohol addiction in adulthood. The relationship of neurobiological processes to the existence of the abovementioned problem has also been proven. These patients have a much lower age of alcohol initiation and a more severe course of the disease itself. The abovementioned group of patients presents a significant therapeutic challenge in addiction therapy due to the complex etiology of the problem and many failures after treatment completion.

\section{Wstęp}

Aktualnie coraz bardziej wzrasta świadomość, że wiele stresujących wydarzeń w ciągu życia może wpływać ma rozwój uzależnień, w tym zespołu uzależnienia od alkoholu (ZUA). Występowanie traumy i stresu w dzieciństwie i w okresie wczesnej dorosłości może nieść za sobą skutki nie tylko bezpośrednie związane z obszarem fizycznym (przykładowo rany, uszkodzenia ciała) oraz psychiczne, takie jak: lęk, izolowanie się dziecka, ale także długofalowe, obserwowane w późniejszym wieku [1-4].

Posługując się definicją Światowej Organizacji Zdrowia (WHO) przemoc wobec dziecka jest doświadczaniem wykorzystywania bądź zaniedbania przez osobę poniżej 18roku życia. Pod takim stwierdzeniem rozumiemy wszystkie formy fizycznego i emocjonalnego krzywdzenia, nadużyć i wykorzystywania seksualnego, zaniedbania, molestowania, wyzysku zarobkowego, którego następstwem jest negatywny wpływ na rozwój, dalsze życie i zdrowie dziecka. Ponadto WHO wyszczególnia 4 formy przemocy wobec dziecka, tj przemoc fizyczną, wykorzystywanie seksualne, przemoc emocjonalna i zaniedbania emocjonalne [5].

Lee i wsp. podkreślali, że w krytycznych, wczesnych etapach rozwoju człowieka, kiedy neuroplastyczność ośrodkowego układu nerwowego jest duża, ekspozycja na wczesnodziecięce traumy może powodować zmiany $\mathrm{w}$ fizjologicznym układzie stresu i prowadzić do rozwoju zaburzenia stresowego pourazowego oraz skłonności do 
nadużywania alkoholu w okresie dorosłości [6].

$\mathrm{Na}$ podstawie przeprowadzonych badań można stwierdzić, że wczesnodziecięcy stres powoduje zmiany w fizjologicznym układzie stresu oraz układzie nagrody w mózgu, który jest również odpowiedzialny za patofizjologię uzależnień. Stresory występujące we wczesnych latach życia prowadzą do zmian w funkcjonowaniu osi podwzgórze-przysadkanadnercza [7,8]. 0 dysregulacji osi podwzgórzeprzysadka-nadnercza u osób uzależnionych od alkoholu, które doświadczyły traumy w dzieciństwie pisali również Zhang i wsp. [9] oraz Lee i wsp.[6].Długotrwałe i intensywne wydzialenie kortyzolu, które jest odpowiedzią na przewlekły stres powoduje, że zmniejsza się ekspresja genów dla receptora kortyzolu a w następstwie dochodzi do wzmożonej ekspresji kortykoliberyny w podwzgórzu $[7,8]$. Kortykoliberyna wpływa modulująco na poziom katecholamin w OUN, m.in. w drogach korowo-prążkowolimbicznych, które są elementem układu nagrody. Powyższe zmiany w funkcjonowaniu układu nerwowego sprzyjają nadużywaniu alkoholu [10].

Strukturalne i funkcjonalne badania neuroobrazowe pokazały, że występowanie stresorów we wczesnych etapach życia, występowanie traumy w dzieciństwie oraz przewlekłego stresu związane są ze zmniejszeniem objętości istoty szarej w brzuszno-przyśrodkowej części kory przedczołowej, ciał migdałowatych, hipokampa oraz wyspy. Ponadto wymienione powyżej stresory mogą zmniejszać odpowiedź w rejonach przedczołowych, odpowiedzialnych za pamięć operacyjną, prawidłowe funkcjonowanie układu nagrody oraz za zdolność radzenia sobie, a zmiany te są z kolei powiązane z dysregulacją emocjonalną i układu nagrody, ze skłonnością do ryzykownego picia alkoholu, a także z kompulsywnym objadaniem się i predyspozycją do zachowań agresywnych [11].

$\mathrm{Na}$ podstawie przeprowadzonych badań stwierdzono, że im cięższa jest trauma tym poważniejsze jej następstwa w dorosłości [1-4].

\section{Cel pracy}

Celem pracy było poszukiwanie zależności pomiędzy występowaniem traumy u dzieci a jej długofalowym skutkiem jakim jest uzależnienie od alkoholu oraz przegląd najnowszych badań dotyczących występowania pewnych charakterystycznych cech osobowości u pacjentów z doświadczeniem traumy dziecięcej oraz czynników prognostycznych w terapii.

\section{Metody}

Dokonano przeglądu literatury za pomocą bazy danych Google Scholar, używając słów kluczy childhood abuse, childhood trauma, alcohol addiction, alcohol use disorder oraz dyskryptorów czasowych 2015-2021.

\section{Wyniki}

Współczesna wiedza medyczna pozwala nam na postawienie tezy, że istnieje związek pomiędzy występowaniem traumy w dzieciństwie a uzależnieniem od alkoholu w wieku dorosłym. Wyniki wielu badań potwierdzają, że doświadczenie ekstremalnych sytuacji stresowych w młodym wieku deklaruje większa część badanych pacjentów z ZUA [2,3]. Dla porównania osoby bez wywiadu uzależnienia od alkoholu stanowią 10 razy mniejszą grupę pacjentów, którzy doświadczyli nadużyć w wieku dziecięcym [1]. Na podstawie aktualnej wiedzy medycznej nie udowodniono z całą pewnością związku pomiędzy występowaniem ekstremalnych sytuacji stresowych u kobiet w ciąży a późniejszym uzależnieniem od alkoholu ich dzieci (większość takich badań była, ze względów etycznych, prowadzona na zwierzętach) [12]. Jednak na podstawie badania z 2020 roku nie znaleziono znaczących korelacji pomiędzy traumatycznymi wydarzeniami w okresie ciąży i wczesnodziecięcym a rozwojem uzależnienia w wieku dorosłym. Stwierdzono jednak, że spożywanie alkoholi niskoprocentowych i częste picie w okresie ciąży przez matkę może predysponować do wystąpienia ZUA u mężczyzn [13].

$\mathrm{Na}$ podstawie przeprowadzonych badań zauważono również, że najistotniejszymi i najczęściej raportowanymi negatywnymi doświadczeniami $\mathrm{z}$ dzieciństwa u pacjentów z ZUA są przemoc fizyczna, separacja lub rozwód rodziców oraz choroba psychiczna członka rodziny. Występują również różnice pomiędzy płciami dotyczące poszczególnych rodzajów zdarzeń w dzieciństwie. Mężczyźni znacznie częściej zgłaszali występowanie przemocy fizycznej, wykorzystania seksualnego, zaniedbania emocjonalnego oraz nieprawidłowe funkcjonowanie $w$ rodzinie. Kobiety dodatkowo zaznaczały przemoc emocjonalną oraz fizyczne zaniedbanie. Istnieje również grupa pacjentów, którzy w dzieciństwie doświadczyli wszystkich zdefiniowanych rodzajów traumy - zaobserwowano, że ta grupa chorych dodatkowo rozwijała znaczące klinicznie zaburzenia psychiczne [1].

Vaughan i wsp. przeprowadzili ciekawe badania, dotyczące występowania predyspozycji do nadużywania alkoholu oraz innych substancji psychoaktywnych i wykorzystali do tego model mysi. W badaniu obserwowano myszy, podzielone na grupy ze względu na wiek i płeć, poddane działaniu stresorów oraz czynników środowiskowych. Autorzy zauważyli ważną korelację pomiędzy doświadczeniem traumy w dzieciństwie a zwiększonym ryzykiem nadużywania alkoholu w dorosłym życiu, szczególnie u kobiet, co może być 
jednak modyfikowalne poprzez sprzyjające warunki środowiskowe [14].

Warty podkreślenia jest również związek pomiędzy występowaniem traumy dziecięcej a cechami osobowości opisywanych dorosłych pacjentów. Na podstawie badania z 2015r stwierdzono, że jednymi z cech charakteryzujących tę grupę chorych są impulsywność, dezorganizacja, pesymizm, męczliwość i astenia. Badacze stwierdzili, że pacjenci ci w większej mierze mają niższy poziom tolerancji frustracji, są bardziej pobudliwi, impulsywni, aktywniej poszukują stymulacji, są mniej systematyczni w podejmowanych działaniach oraz podejmują aktywności nieograniczone regułami i zasadami. Problemem dotykającym te osoby jest również niski poziom samoakceptacji, niższa wyrozumiałość i wyrozumiałość na potrzeby i uczucia innych. Zauważono, że pacjenci ci przejawiają większy poziom agresji, co również może predysponować do większego ryzyka samobójstwa[15,16]. Porównując tę grupę badanych do populacji ogólnej można stwierdzić, że charakteryzuje ich także wyższy poziom lęku uogólnionego, co jest czynnikiem niekorzystnym rokowniczo w terapii [17-19].

Współistnienie traumy dziecięcej i uzależnienia od alkoholu niesie ze sobą wiele wyzwań terapeutycznych. Zaobserwowano niski wiek inicjacji alkoholowej w tej grupie pacjentów; ponadto znacznie wcześniej rozwijał się u nich zespół uzależnienia od alkoholu a sama choroba miała wyraźnie cięższy przebieg [20-21]. Powyżej opisane cechy osobowości pacjentów z ZUA mogą predysponować do niepowodzeń terapeutycznych i wczesnych nawrotów picia po przebytej terapii odwykowej $[1,17,22,23]$. W badaniu z roku 2019 naukowcy doszli do wniosku, że w 12 miesięcznym okresie obserwacji grupa kobiet z wywiadem traumy dziecięcej znacznie częściej wracała do nałogu niż kobiety bez współistniejących obciążeń stresowych [24]. Leczenie takiej grupy pacjentów powinno być ukierunkowane na działanie kompleksowe. Nie wolno traktować samego uzależnienia i samej traumy dziecięcej jako oddzielnych jednostek chorobowych. Według najnowszych badań najefektywniejsze jest prowadzenie terapii równolegle dotykając problemu traumy dziecięcej i uzależnienia; należy tak pokierować terapią pacjenta, aby dostrzegł on związek przyczynowo-skutkowy [4].

\section{Wnioski}

Na podstawie najnowszych wyników badań można stwierdzić, że istnieje znacząca korelacja pomiędzy występowaniem traumatycznych wydarzeń w wieku dziecięcym a skłonnością do uzależnienia od alkoholu w wieku dorosłym. Udowodniono również związek procesów neurobiologicznych na istnienie powyższego problemu. Pacjenci ci mają znacznie niższy wiek inicjacji alkoholowej oraz cięższy przebieg samej choroby.
Powyższa grupa chorych stanowi znaczne wyzwanie terapeutyczne $\mathrm{w}$ terapii uzależnień $\mathrm{z}$ powodu złożonej etiologii problemu i wielu niepowodzeń po zakończeniu leczenia.

\section{Conflict of interest}

The authors have declared no conflict of interest.

\section{References}

1. Zaorska J, Jakubczyk A. Rozpowszechnienie i znaczenie traumy dziecięcej w grupie pacjentów uzależnionych od alkoholu, Chair and Deartment od Psychiatry, Warsaw Medical University Poland Online publish date: 2019/08/30 Alcohol Drug Addict 2019; 32 (2): 131-152

2. Dragan M. Doświadczenia traumatyczne a uzależnienie od alkoholu. Warszawa: Wydawnictwo Uniwersytetu Warszawskiego; 2008.

3. Skotnicka J. Ekspozycja na doświadczenia traumatyczne wśród osób uzależnionych od alkoholu. Psychiatr Pol 2018; 52(3): 48797.

4. Bremner JD. Long-term effects of childhood abuse on brain and neurobiology. Child Adolesc Psychiatr Clin N Am 2003; 12(2): 271-92.

5. WHO https://www.who.int/news-room/fact-sheets/detail/ child-maltreatment

6. Lee RS, Oswald LM, Wand GS. Early Life Stress as a Predictor of Co-Occurring Alcohol Use Disorder and Post-Traumatic Stress Disorder. Alcohol Res. 2018;39(2):147-159

7. Heim C, Nemeroff $C B$. The role of childhood trauma in the neurobiology of mood and anxiety disorders: preclinical and clinical studies. Biol Psychiatry 2001; 49(12): 1023-39.

8. Nemeroff CB. Neurobiological consequences of childhood trauma. J Clin Psychiatry 2004; 65 Suppl 1: 18-28.

9. Zhang A, Price JL, Leonard D, North CS,Suris A, Javors MA,et al. Alcohol Use Disorder Masks the Effects of Childhood Adversity, Lifetime Trauma, and Chronic Stress on HypothalamicPituitary-Adrenal Axis Reactivity. Alcohol Clin Exp Res. 2020 Jun;44(6):1192-1203.

10. Herman JP, Ostrander MM, Mueller NK, Figueiredo H. Limbic system mechanisms of stress regulation: hypothalamopituitary-adrenocortical axis. Prog Neuropsychopharmacol Biol Psychiatry 2005; 29(8): 1201-13.

11. Barros Guinle MI, Sinha R. The Role of Stress, Trauma, and Negative Affect in Alcohol Misuse and Alcohol Use Disorder in Women. Alcohol Res. 2020 Aug 20;40(2):05. doi: 10.35946/arcr. v40.2.05.

12. Bell RL, Lopez MF, Cui C, et al. Ibudilast reduces alcohol drinking in multiple animal models of alcohol dependence. Addict Biol. 2015;20(1):38-42

13. Wang, CXA, Song M, Li N, Gao YY, Zhao XC, Yu LL, Wang YM, Wang XY. Evaluation of childhood traumatic experience as a risk factor for alcohol use disorder in adulthood.BMC Psychiatry volume 20, Article numer 15 (2020)

14. Vaughan G, Kompanijec K, Malik S, Bechard AR. Childhood trauma and post-trauma environment affect fear memory and alcohol use differently in male and female mice. Drug Alcohol Depend. 2021 Feb 1;219:108471.

15. Roy A, Jana N. Risk factors for suicide attempts among alcohol dependent patients. Arch.Suicide Res. 2007; 11(2): 211-217.

16. Koller G, Preuss UW, Bottlender M, Wenzel K, Soyka M. Impulsivity and aggression as predictors of suicide attempts in alcoholics. Eur. Arch. Psychiatry Clin. Neurosci. 2002; 
252(4):155-160

17. Gerhant A, Olajossy M. Cechy osobowości u osób uzależnionych od alkoholu $\mathrm{w}$ kontekście doświadczeń przemocy w dzieciństwie, Psychiatr. Pol. 2016; 50(5): 973-987

18. Willinger U, Lenzinger E, Hornik K, Fischer G, Schönbeck G, Aschauer HN. i wsp. Anxiety as a predictor of relapse in detoxified alcohol-dependent patients. Alcohol Alcohol. 2002; 37(6):609-612.

19. Schellekens AFA, de Jong CAJ, Buitelaar JK, Verkes RJ. Co-morbid anxiety disorders predict early relapse after inpatient alcohol treatment. Eur. Psychiatry 2015; 30(1): 128-136

20. Brady KT, Back SE. Childhood trauma, posttraumatic stress disorder, and alcohol dependence. Alcohol Res 2012; 34(4): 40813.

21. Lotzin A, Haupt L, von Schonfels J, Wingenfeld K, Schafer I. Profiles of Childhood Trauma in Patients with Alcohol Dependence and Their Associations with Addiction-Related Problems. Alcohol Clin Exp Res 2016; 40(3): 543-52.

22. Sellman JD, Mulder RT, Sullivan PF, Joyce PR. Low persistence predicts relapse in alcohol dependence following treatment. J. Stud. Alcohol. 1997; 58(3): 257-263.

23. Müller SE, Weijers HG, Böning J, Wiesbeck GA. Personality traits predict treatment outcome in alcohol-dependent patients. Neuropsychobiology 2008; 57(4): 159-164.
24. Schückher F, Sellin T, Engström I, Berglund K.History of childhood abuse is associated with less positive treatment outcomes in socially stable women with alcohol use disorder .BCM Women Health 2019, Dec 12;19(1):159.

\section{Corresponding author}

Ewa Stelmach

II Department of Psychiatry and

Psychiatric Rehabilitation

Medical University of Lublin

Głuska 1 Street, 20-439 Lublin, Poland

+48817440967

ewastelmach@umlub.pl

Otrzymano: 19.03.2021

Zrecenzowano: 24.03.2021

Przyjęto do druku: 29.03.2021 